been isolated from among the products of bacterial action on either glycerol or lactate, although the formation of glucose in cultures of Poria vaillantii on a glycerol medium has been reported by Sison and Schubert ${ }^{4}$, while Horecker ${ }^{5}$ has suggested a cyclic mechanism by which this conversion may be effected.

It is proposed to report the work in further detail elsewhere.

One of us (K. R.) acknowledges the receipt of an Imperial Chemical Industries Research Fellowship.

C. P. JACKSON

K. Ramamurti

College of Science and Technology, University of Manchester.

${ }^{1}$ Hughes, R. C., and Whelan, W. J., Chem. and Indust., 884 (1958). ${ }^{2}$ Lemieux, R. U., Bishop, C. T., and Pelletier, G. E., Can. J. Chem.,

3 Bourne, E. J., and Weigel, H., Chem. and Indust., 182 (1954).

4 Sison, B. C., and Schubert, W. J., Nature, 181, 1015 (1958).

${ }^{5}$ Horecker, B. L., Brewers Digest, 28, 214 (1953).

\section{Distribution of Protein-bound Aminoazo Dyes in the Rat Liver Microsome}

Evidence has been obtained that rat liver microsomes are the site where the formation of protein. bound aminoazo dyes occurs ${ }^{1-3}$. On the other hand, one of the most important parts played by the microsome is known to be protein synthesis. Littlefield et al. ${ }^{4}$ further fractionated the microsome by means of sodium deoxycholate and pointed out that the protein in the deoxycholate-insoluble fraction, ribonucleoprotein particles, showed a particularly high turn-over rate, suggesting that protein is in fact synthesized in this fraction. This suggestion was supported by other authors ${ }^{5-7}$.

In investigating the carcinogenesis due to aminoazo dyes, it is an inevitable question whether the protein-bound dye is detectable even in the fraction with such a high turn-over rate as the microsome ribonucleoprotein fraction. Despite the fact that Arcos and Arcos $^{3}$ are inclined to the view that no protein-bound dye was found in this fraction, we repeated a similar experiment but on a somewhat larger scale, since their evidence seemed to be inconclusive.

Rats which were fed 3'-methyl-4-dimethylaminoazobenzene coated on rice $(0.06$ per cent) were killed after 2 weeks when the protein-bound dye is considered to be a maximum. The liver microsomes were prepared according to Schneider's method ${ }^{8}$ and washed once with $0.25 M$ sucrose solution. The unsedimented fluid was designated as "supernatant fraction'. The microsomes were further fractionated by means of sodium deoxycholate as proposed by Littlefield et al. ${ }^{4}$. Thus we obtained three fractions, namely, deoxycholate-insoluble fraction (ribonucleoprotein fraction) and deoxycholate-soluble fraction from microsomes and the supernatant fraction. A small portion of each fraction was withheld for the protein $^{9}$ and ribonucleic acid ${ }^{4}$ assays and the rest was subjected to protein-bound dye (polar dye) determination $^{10,11}$.

The results are summarized in Table 1. This clearly shows that a definite amount of proteinbound dye is detected in the ribonucleoprotein fraction. The total amount of this protein-bound dye in the ribonucleoprotein fraction is obviously lower than that in the other fractions. If, however, the proteinbound dye concentration is expressed on a per unit
Table 1. Distribution of Polar Dye among Cell Fraction

\begin{tabular}{|c|c|c|c|c|}
\hline & Fraction & $\begin{array}{r}\text { Miero } \\
\text { deoxye } \\
\text {-insoluble }\end{array}$ & $\begin{array}{l}\text { some } \\
\text { holate } \\
\text {-soluble }\end{array}$ & Supernatant \\
\hline \multirow[t]{5}{*}{ Exp. 1} & Liver used (gm.) & \multicolumn{2}{|c|}{87} & \multirow{9}{*}{2,700} \\
\hline & $\begin{array}{l}\text { Protein (mgm.) } \\
\text { Ribonucleic acid }\end{array}$ & 105 & 750 & \\
\hline & (mgm.) & 63 & $3 \cdot 0$ & \\
\hline & $\begin{array}{l}\text { Polar dye }(\gamma)^{*} \\
\text { Polar dye }(\gamma) / 100\end{array}$ & $2 \cdot 6$ & 27 & \\
\hline & mgm. protein & $2 \cdot 5$ & $3 \cdot 6$ & \\
\hline \multirow{4}{*}{ Exp. 2} & $\begin{array}{l}\text { Liver used (gm.) } \\
\text { Protein (mgm.) }\end{array}$ & 65 & 530 & \\
\hline & Ribonucleic acid & & & \\
\hline & Polar dye $(\gamma)^{*}$ & $2 \cdot 0$ & 15 & \\
\hline & $\begin{array}{l}\text { Polar dye }(\gamma) / 100 \\
\text { mgm. protein }\end{array}$ & & $2 \cdot 8$ & \\
\hline
\end{tabular}

* The amount of polar dye is expressed in terms of DAB tentatively.

mgm. protein basis, the figures for the three fractions stand very closely to each other.

The significance of the finding must await further experiments, which are now being carried out here.

This experiment was supported partly by the grant from the Ministry of Education, Japan.

T. YAMADA

M. Matsumoto

S. KANDA

H. Terayama

Department of Biophysics and Biochemistry, Faculty of Science,

University of Tokyo, Tokyo.

${ }^{1}$ Hultin, T., Exp. Cell Res., 10, 71, 697 (1956); 13, 47 (1957).

${ }^{2}$ Gelboin, H. W., Miller, J. A., and Miller, E. C., Cancer Res., 18, 618 (1958)

${ }^{3}$ Arcos, J. C., and Arcos, M., Biochim. Biophys. Acta, 28, 9 (1958). Littlefield, J. W., Keller, E. B., Gross, J., and Zamecnik, P. C.,
J. Biol. Chem., 217, 111 (1955).

${ }^{3}$ Alfrey, V. G., Daly, M. M., and Mirsky, A. E., J. Gen. Physiol., 37, 157 (1953)

${ }^{6}$ Hultin, T., Exp. Cell. Res., Supp., 8, 210 (1955).

'Simkin, J. L., and Work, T. S., Biochem. J., 65, 307 (1957).

Schneider, W. C., and Hogeboom, G. H., J. Biol. Chem., 183, 123 (1950).

'Lowry, O. H., Rosebrough, N. J., Farr, A. L., and Randall, R. J., J. Biol. Chem., 198, 265 (1951).

10 Terayama, H., Kusama, K., Teruya, K., Kuroda, S., and Nakayama, T., Gann, 49, 85 (1958).

${ }^{11}$ Terayama, H., Kusama, K., and Aoki, T., Gann, 49, 97 (1958).

\section{Water-soluble, Non-fibrous Deoxyribonucleoprotein from Calf Thymus Nuclei}

A WATER-SOLUBLE, non-viscous form of deoxyribonucleoprotein has been isolated from purified calf thymus nuclei by a process that minimizes enzyme degradation. Previously the only preparation of deoxyribonucleoprotein generally accepted as undegraded has been the fibrous one, forming gels in water and only slightly soluble, with a molecular weight of 17 million ${ }^{1}$.

Fresh calf thymus glands are frozen immediately on removal from the animal and ground to a powder in the frozen state in the presence of 'dry ice'. Only this procedure has been found to produce intact, round nuclei, as confirmed by microscopic examination, without excessive clumping, when the ground material is suspended in the purification medium at $0-4^{\circ} \mathrm{C}$.

The purification medium is modified from those of Dounce et al. ${ }^{2}$ and Philpot and Stanier ${ }^{3}$, and is composed of $0.44 M$ sucrose, 40 per cent glycerol, $0.039 M$ sodium glycerophosphate, $0.019 M$ citrate buffer $(p \mathrm{H} \cdot 6 \cdot 1$, ionic strength $0 \cdot 15)$. 